\title{
The status of Rotalia Lamarck (Foraminifera) and of the Rotaliidae Ehrenberg
}

\author{
JOHN R. HAYNES ${ }^{1} \&$ JOHN E. WHITTAKER ${ }^{2}$ \\ 1 Institute of Earth Studies, University College of Wales, Aberystwyth, Dyfed, SY23 3DB \\ 2 Department of Palaeontology, British Museum (Natural History), Cromwell Road, London, SW7 5BD.
}

\begin{abstract}
One damaged specimen remains in the Lamarck Collection, Geneva, from the original type series of Rotalia trochidiformis (Lamarck) the remainder of which was included in the Defrance Collection in Caen, all of which was destroyed in World War II. Restudy of this sole remaining paralectotype, together with topotypes and other material held in the British Museum (Natural History) has revealed the morphological changes that occur with ontogeny in this species and has made an emended generic diagnosis necessary. In the adult, R. trochidiformis develops open septal canals with a tributary system of secondary and tertiary fissures by resorption and a dense mass of vertical pillars which effectively destroy the umbilical cover plate seen in the juvenile. The septal canals connect with the umbilical canal via supplementary apertures and with vertical canals between the umbilical pillars. They also connect with the foraminal passage via subsutural canals. The idea the Rotalia should be reassigned to the Discorbidae is rejected and the integrity of the Rotaliidae is affirmed.
\end{abstract}

\section{INTRODUCTION}

The early history of the taxonomic treatment of Rotalia trochidiformis (Lamarck, 1804) is thoroughly reviewed by Davies in his emendation and redescription of 1932. His conclusion was as follows (op,cit.: 411): 'It seems clear that Rotalites trochidiformis is the species which pre-eminently represents Lamarck's genus Rotalia. It is the first to be described and figured under that heading; and the only species mentioned at the time which fully matches the original description of the genus. It is true that the term Rotalia was first regarded as a mere equivalent of Rotalites, and that another species had previously been named as representing Rotalites [Rotalites tuberculosa Lamarck, 1801]; but the latter species had never been recognisably indicated, and its own author had not only abandoned it but had also completely revised the generic description which he had drawn up to suit it. The revised generic description, with its alternative name of Rotalia, clearly applies to the species trochidiformis and not to tuberculosa'.

The clear distinction that was made by Lamarck (1804) in erecting his genera Discorbis (D. vesicularis) and Rotalia became blurred under the influence of the extreme 'lumping' of the 'English School' in the mid-nineteenth century. Carpenter, Parker \& Jones (1862) included both Discorbis and Rotalia in their new genus Discorbina (a junior synonym) and thus offended against the Articles of the International Code of Zoological Nomenclature. Brady (1884) similarly took a wide view of 'Discorbina'. He noted that its chief diagnostic character was the presence of umbilical lobes,... 'In fullest development they are separated by marked constrictions from the body of the segments and form supplementary chambers... sometimes they form solid masses of shell substance, filling the umbilicus, and marked externally with exogenous tubercles'. However, he gave separate recognition to Rotalia, noting that the majority of species had double septa (following Carpenter, Parker \& Jones, 1862); these two forms again had umbilical chamberlets and some had a "more or less complicated canal system". He also considered the fine wall structure and minute pores characteristic. Unfortunately, he chose 'Rotalia' beccarii (Linné) as the "central species" which again offends the International Code of Zoological Nomenclature. It also happens to be the type of Ammonia Brünnich, 1772.

The first worker to provide reasonable accurate drawings of specimens of Rotalia trochidiformis showing a growth series, from the type locality of Grignon in the Paris Basin, was Cushman (1927). His drawiings show a juvenile with pointed umbilical lobes, radial, excavated sutures and incipient side fissures, a second, larger juvenile with coalesced lobes and development of pillars and a third quite well-grown specimen with the ventral side completely incised with full development of pillars. The implications of these marked differences have since been overlooked.

Cushman's observations were confirmed and extended by Davies (1932) who examined the original type material of Lamarck from Grignon (Defrance Collection in the Muséum d'Histoire naturelle, Caen) together with other material from Parnes and Chaussy in the Paris Basin as well as from the Contentin, housed in the British Museum (Natural History), London and in the École des Mines, Paris. The material examined by Davies also included the one damaged specimen from the original Lamarck Collection, housed in the Muséum d'Histoire naturelle, Geneva.

The results of this work which included the sectioning of a number of specimens led to the conclusion that the following 
features were generically diagnostic: the presence of double septa expressed as radial furrows on the ventral side: a transverse septum separating off the inner portion of the chamber (astral lobe) marked by a notch (astral furrow). The progressive development of pillars which tend to be confined to each whorl was also mentioned but not stressed. Davies denied that an umbilical or septal canal system existed, neither did he mention the presence of a dendritic network of fissures. Davies selected a lectotype from the original type series, a juvenile that best showed the umbilical features. Unfortunately, the specimen was destroyed with the rest of the type series in a bomb attack on Caen during World War II (Maync, 1952), leaving the Geneva specimen the sole remaining primary type, the only paralectotype.

It might have been thought that this detailed study would have settled most of the outstanding questions concerning the nature of the genus Rotalia. In fact, confusion has continued down to the present day. This arises, in part because although the type species has been recorded as occurring abundantly in high level, shallow water sediments deposited at the height of the successive Palaeogene transgressions, typical forms (i.e. Rotalia trochidiformis sensu stricto) are confined to the Middle Eocene, possibly even to the Paris Basin. Not only are specimens from elsewhere smaller but they are often much altered, recrystallised and even dolomitised, usually with the last chamber broken. For this reason Smout (1954) was unable to determine the apertural characters in his specimens from Qatar. He also denied the existence of the umbilical chamberlets or 'astral lobes' claimed by Davies, although the excellent figures of his lectotype clearly do show discorbidlike umbilical lobes.

Another reason for confusion is the difficulty of observing test details by the light-microscope and also of evaluating the importance of the new features revealed by the advent of scanning electron microscopy (Barker \& Grimsdale, 1937; Reiss \& Merling, 1958; Loeblich \& Tappan, 1964; Hofker, 1971; Parvati, 1971; Müller-Merz, 1980; Lévy et al., 1982, 1984, 1986). The latest work (Hofker, 1971; Parvati, 1971; Müller-Merz, 1980; Lévy et al., 1982), shows that the partial partition which cuts off the astral lobe is quite similar to that in Discorbis. This brings us back to the mid-nineteenth century view of the close relationship of the two genera, especially if one accepts the view of Carpenter, Parker \& Jones (1862) that there are no canals, as do Davies (1932), Reiss \& Merling (1958), Lévy et al., (1982, 1984, 1986). On the other hand, Smout (1954), Loeblich \& Tappan (1964. 1988), Hofker (1971) and Parvati (1971) argue for the existence of an umbilical or spiral canal as well as sutural canals.

Lévy et al. (1986) also deny that double septa are unique to the rotaliids and claim that they occur in Discorbis and a number of related genera. This leads them to subsume the Rotaliidae within the Discorbidae, with drastic repercussions for taxonomy.

In hope of solving some of these problems we have reexamined Davies' material in the British Museum (Nat. Hist.) and re-illustrated key specimens by scanning electron microscopy, as well as the sole remaining specimen from the Lamarck Collection kindly lent to us by the Muséum d'Histoire naturelle de Genève, Switzerland. As this remaining type specimen (the sole paralectotype, following the destruction of Davies' lectotype) is badly damaged we have redescribed the genus and species on the basis of three additional undamaged topotypes from Grignon and other specimens from the Davies Collection from Parnes and Chaussy, nearby in the Paris Basin, which together represent a growth series (see Plates 1, 2, Text fig. 2, and also pl. 3, Text-figs 1,3 for internal features). Efforts were made to obtain adult specimens from Grignon but, as pointed out by Professors J.W. Murray (letter 25.2.87) and D. Curry (letter 1.4.87), the species is actually very rare there, with a known maximum diameter of $1.5 \mathrm{~mm}$, and the classic pit is now closed. We have therefore illustrated two specimens from the Murray \& Wright Collection in the British Museum (Nat.Hist.) and another, larger specimen from Professor Murray's personal collection, subsequently donated, near the maximum size for the specimens found during recent years at the type locality.

\section{SYSTEMATIC DESCRIPTIONS}

Order Rotaliida Lankester, 1885

Superfamily Rotaliacea Ehrenberg, 1839

Family Rotaliidae Ehrenberg, 1839

Subfamily Rotaliinae Ehrenberg, 1839

Genus Rotalia Lamarck, 1804, emend

Type Species: Rotalites trochidiformis Lamarck, 1804.

Emended generic diagnosis. Test trochospiral with angular or keeled periphery; dorsal side evolute, ventral side involute with simple, arched basal aperture; umbilicus on ventral side secondarily closed by imperforate, sub-triangular lobes ('astral lobes'), well developed in juveniles and seen extending from the last few chambers in adults; lobe separated from primary chamber cavity by a deep notch ('astral furrow') and partial partition ('toothplate') which continues as a septal flap over the previous apertural face producing a 'double septum'; distal end of lobe pointed with peripheral lip and tucked into umbilical end of the aperture, effectively making the distal notch a supplementary aperture which communicates with the primary chamber via an umbilical opening; ventral septal sutures deeply entrenched and prolonged across umbilical lobes by resorption to form open canals; with growth there is a progressive modification of these open canals between earlier chambers to produce a dendritic network of secondary and tertiary fissures which divide the chamber walls and umbilical lobes and feed into the septal canals; granules develop between the fissures becoming strong vertical pillars, these remain more or less confined to the chambers and lobes but partially fuse to become a complex umbilical plug; the zone of supplementary apertures and notches tends to remain clear in the last few chambers as an umbilical canal ('space') and the septal canals communicate with this spiral canal via the supplementary apertures and irregular vertical canals in the umbilical mass. Communication between the main chamber lumen and the umbilical area is via vertical, subsutural 
canals ('interlocular space') linking the foramina with the septal canals. Initially, there is free communication into the umbilical area from beneath the astral lobe, with a definite arched opening ('labial aperture') beneath the distal lip.

Remarks. The chief differences between our emended diagnosis compared with that given by Loeblich \& Tappan (1988) arise because we have been able to show that there are important developments during ontogeny, as follows:

(a) The pointed end of the astral lobe is tucked into the aperture, making the distal notch ('astral furrow') into a supplementary aperture which communicates with the primary chamber via the umbilical opening and foraminal passage.

(b) The groove beside the distal lip of the astral lobe becomes the site of the extension of the septal canal when the next chamber is added. The septal canal connects with the foraminal passage via a subsutural canal ('interlocular space') between the septal flap and the previous apertural face, as well as with the previous supplementary aperture.

(c) With growth the development of the open canal system and pillars destroys the umbilical cover plate present in the juvenile, taking over almost the entire umbilical area in the adult.

Septal canals are not mentioned in their diagnosis, only fissures which are defined as deeply cleft or incised sutures. The diagnoses agree, however, in emphasising the angular or keeled periphery, the presence of a spiral umbilical canal and the septal flap.

\section{Rotalia trochidiformis (Lamarck) emend.} (Plates 1-3; Text-figs. 1-3.)

Rotalites trochidiformis Lamarck, 1804: 184; 1806: 387, pl 62(14), figs. 8a, b; Favre, 1918: pi. 2, figs. 12a-c.

Rotalia trochidiformis (Lamarck), Bronn, 1824: 49, pl. 1, figs. 7a, b; d'Orbigny, 1826: 272; Cushman, 1927: 124, pl. 24, figs, 5,6; 1928: 273, pl. 40, figs. 3,4; Davies, 1932: 408, textfigs. 4-9, pl. 2, figs, $8,10-15$, pl. 3, figs. 1-13, pl. 4, figs. 3-6, 9-11, (lectotype, pl. 3, figs. 4,5,7); ?Gill, 1953: 840, pl. 90, figs. 1-12; Haque, 1962: 19, pl.2, figs. 1-3; Lévy et al., 1982: 34, pl.1, figs. 1-9, pl.2, figs. 1-9, 1986: 65-67, 69, pl. 1, figs. 4,8,9, 12; Müller-Merz, 1980: 34,35, text-figs. 16,17, pl.2, figs. 1-3; Murray \& Wright, 1974: pl. 11, figs. 4,5; Parvati, 1971: 5,text-fig. 1, pl.1, figs. 1-5, pl.4, fig. 1; ?Smout, 1954: 43, pl.1, figs. $1-6$.

Rotulites trochidiformis (Lamarck), Brown, 1839: 61, pl. 10, fig. 16

Rotalina (Rotalina) trochidiformis (Lamarck), Reuss, 1846: 674, pl. 24, figs. 5 la, b.

Discorbina trochidiformis (Lamarck), Carpenter, Parker \& Jones, 1862: 204, 205.

Descriptions. Rotalia trochidiformis shows marked morphological changes with ontogeny and different populations are often dominated by different growth stages. Because this has caused confusion in the past we have taken the opportunity provided by the British Museum (Nat. Hist.) collections to describe and illustrate a full growth series before giving a summary description. The sequence is shown in Plate 1,2; Text fig. 2:

Topotype (British Museum (Nat. Hist.) no. P 49283, Pl 1, figs. 1-1): Test trochoid, sinistral, biconvex with evolute dorsal side slightly higher than the involute ventral side; periphery acute, keeled, entire; about $2 \frac{1}{2}$ whorls of chambers visible on the dorsal side with marked, slightly thickened whorl suture; rate of chamber size increase as added, low, shape trapezoid, sutures backward curving, flush; 7 chambers visible on ventral side with elongate, triangular umbilical (astral) lobes fused together to form partial coverplate; astral lobes separated from primary chamber cavity by a deep distal notch (astral furrow) and partial partition (toothplate); distal end of final lobe bears a reflexed lip and is tucked into umbilical side of the simple, basal aperture, making the distal notch a supplementary aperture; septal sutures curved, deeply excavated and continued across lobes of previous chambers by resorption to form open canals (fissures); edges of the last two chambers plicated and granulated along the septal canals while earlier chambers show strong development of vertical pillars and secondary and tertiary fissures cutting back into the walls; pores densely and evenly developed on the dorsal side, restricted to the central area of the chambers on the ventral side, keel and astral lobes imperforate.

Dimensions: Maximum diameter $1.1 \mathrm{~mm}$, height $0.50 \mathrm{~mm}$. Provenance: From Middle Eocene (M. Lutetian), original type locality at Grignon (lat. $48^{\circ} 51^{\prime} \mathrm{N}$, long. $1^{\circ} 57^{\prime} \mathrm{E}$ ), a few kilometres west of Versailles, Paris Basin, France.

Depository: British Museum (Nat.Hist.), reg. no. P 49283, Murray \& Wright Collection. Formerly illustrated in Murray \& Wright (1974, pl. 11, figs, 4,5).

Topotype (British Museum (Nat. Hist.) no. P 52260, Pl. 1, figs. 2.2,3): A well preserved specimen with unbroken last chamber. It has about 3 whorls with 8 chambers visible on the ventral side. The progressive break-up of the juvenile coverplate has proceeded further in this case and the prolongation of the entrenched septal canals by resorption is well shown. Dimensions: Maximum diameter $1.46 \mathrm{~mm}$, height $0.55 \mathrm{~mm}$. Provenance: From Middle Eocene (M. Lutetian), original type locality at Grignon, Paris Basin, France. From sample F132, Murray \& Wright (1974).

Depository: British Museum (Nat. Hist.), reg. no. P 52260 , donated by Professor J.W. Murray, 1987.

Hypotype (British Museum (Nat. Hist.) no. P 52261 , PI. 1. figs. 4-4,5,6); A well preserved adult specimen with unbroken final chamber in which the details closely correspond to those of the topotypes (Pl.1). It has about 4 whorls and 10 chambers visible on the ventral side. The keel is more strongly developed and the growth of fissures and pillars has largely destroyed the umbilical cover-plate seen in the topotype (P 49283, Pl. 1, Fig. 1-1). Apertural details are particularly well shown.

Dimensions: Maximum diameter $2.33 \mathrm{~mm}$, height $1.17 \mathrm{~mm}$ Provenance: From the Calcaire Grossier, Middle Eocene (Lutetian), Chaussy (Lat. $49^{\circ} 07^{\prime} \mathrm{N}$, Long. $1^{\circ} 42^{\prime} \mathrm{E}$ ), Paris Basin. 


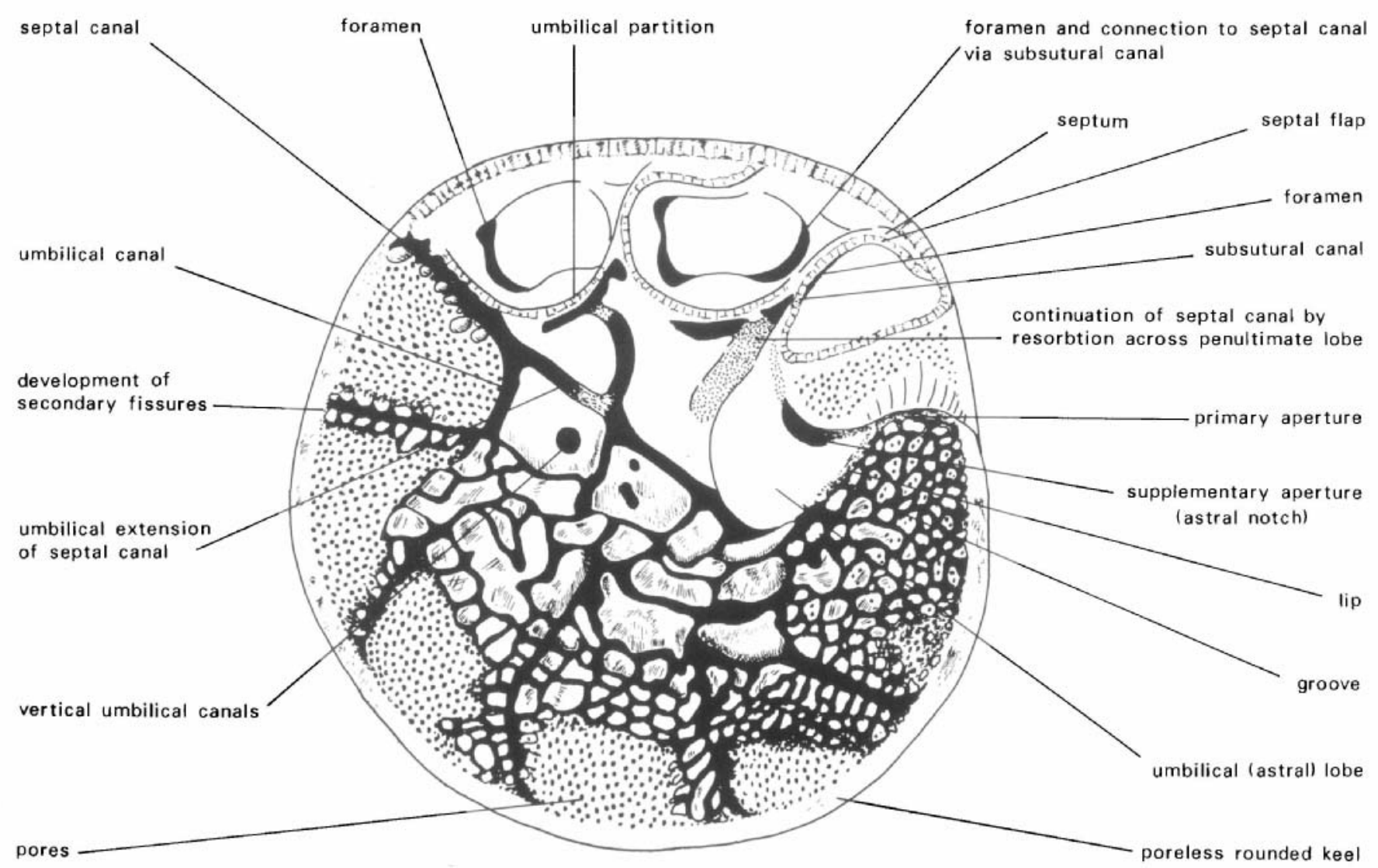

Fig. 1. Diagram of Rotalia trochidiformis (Lamarck) with last three chambers and adjacent umbilical area cut away to reveal the umbilical partitions and secondarily doubled septa, formed by the infolding of the wall of subsequent chambers, and the foramina and their connections with the septal canals via subsutural canals. Note the progressive development of the septal canals, secondary and tertiary fissures and pillars. Drawing built up from a number of broken specimens in the British Museum (Nat.Hist.) collection and from the SEM photographs of Miiller-Merz (1980). Note that the pillars which should appear in the roof of each cutaway chamber (formed by the ventral surface of the previous whorl) are left out for diagrammatic clarity.

Depository: British Museum (Nat. Hist.) reg. no. P 52261, ex L. M. Davies Collection.

Hypotype (British Museum (Nat. Hist.) no. P 27275, Pl. 2, figs. 1-1): A specimen with broken last chamber revealing septal flap and its extension into a toothplate (broken). Final umbilical (astral) lobe broken, revealing the extension of the septal canal by resorption across the astral lobe of the penultimate chamber. Previous astral lobes broken up by progressive development of vertical pillars and dendritic fissuring but astral furrows still visible in ante-penultimate and penultimate chambers. There are 9 chambers visible on the ventral side.

Dimensions: Maximum diameter $2.30 \mathrm{~mm}$. height $1.20 \mathrm{~mm}$. Provenance: From the Calcaire Grossier, Middle Eocene (Lutetian), Chaussy, Paris Basin.

Depository: British Museum (Nat. Hist.) reg. no. P27275, ex T.R. Jones Collection. Figured by Davies (1932, pl.4, fig. 3). Hypotype (British Museum (Nat. Hist.) no. P 27276, Pl. 2, figs. 2-2): A specimen with about $4 \%$ whorls and 11 chambers visible on the ventral side. Last chamber broken revealing septal flap. Development of vertical pillars has broken up the astral lobes and only the penultimate chamber shows a clear astral furrow (secondary aperture). Pillars in umbilical area relatively large.

Dimensions: Maximum diameter $2.26 \mathrm{~mm}$, height $1.30 \mathrm{~mm}$. Provenance: From the Calcaire Grossier, Middle Eocene (Lutetian), Chaussy, Paris Basin.

Depository: British Museum (Nat. Hist.) reg. no. P 27276 , ex T.R. Jones Collection. Figured by Davies (1932, pl. 4, fig. $6)$.

Hypotype (British Museum (Nat. Hịst.) no. P 934, Pl. 2, fig. 3 ): A well grown dextral adult of approximately 5 whorls with 13 chambers visible on the ventral side. Test damaged with last two chambers removed and some earlier ones damaged. In this specimen the development of vertical pillars and dendritic fissures has proceeded to the point where very little of the original surface of the chambers remains unaltered in the early part of the last whorl.

Dimensions: Maximum diameter $3.23 \mathrm{~mm}$, height $1.86 \mathrm{~mm}$. Provenance: From the Middle Eocene (Lutetian), Parnes, 




Fig. 2, 1-3 Rotalia trochidiformis (Lamarck), Paralectotype. Dorsal, edge and ventral views. x22. Muséum d'Histoire naturelle de Genève, Lamarck Collection. Figured by Favre (1918: pl. 2, figs 12a-c) and by Davies (1932: pl. 2, fig. 8). From Grignon, Paris Basin. Mid-Lutetian, M.Eocene. Note the vertical canals in the polished down umbilical mass in fig. 3 . Scanning electron micrographs; backscattered electron images of uncoated material in an 'environmental chamber'; using the method described by Taylor (1986).

near Magny, NW of Paris (lat. $49^{\circ} 13^{\prime} \mathrm{N}$, long, $1^{\circ} 45^{\prime} \mathrm{E}$ ). Depository: British Museum (Nat. Hist.) reg. no. P 934, ex L.M. Davies Collection. Figured by Davies (1932, pl. 3, fig. 13, pl. 4, fig. 9).

Paralectotype (Mus. Hist. nat. de Genève, Text-fig. 2, 1-3): A well grown, sinistral adult with approximately $4 \frac{1}{2}$ whorls and 12 chambers visible on the ventral side. Test badly damaged with last two chambers missing, a broken edge and the ventral side partly polished down. It does, however, reveal the septal flap passing into a lip above the foremen of the last (preserved) chamber and the broken toothplate. The polished ventral side also reveals the continuation of the septal canals across and into the complex umbilical plug and which connect with the umbilical space via the secondary apertures and vertical canals. The raised spiral suture of the species is strongly marked on the dorsal side.

Dimensions: Maximum diameter about $3.00 \mathrm{~mm}$.

Provenance: From Middle Eocene (M. Lutetian), original type locality at Grignon, Paris Basin.

Depository: Muséum d'Histoire naturelle de Genève, Switzerland, Lamarck Collection, sole remaining specimen. Figured by Favre (1918, pl. 2, figs. 12a-c) and by Davies (1932, pl. 2, fig. 8).

Additional Specimens Showing Internal Details:

Topotype: (British Museum (Nat. Hist.) no. P 52262, Pl. 3, figs 1,3-5): Specimen a relative juvenile but near the maximum size of those lately recovered from the type locality, broken across to give a quasi-vertical section and also broken at the periphery to reveal interior of last two chambers. This specimen shows very well the 'labial aperture' beneath the distal lip of the final astral lobe, the supplementary aperture within the astral notch, the internal foramina and foraminal passage as well as the umbilical opening beneath the astral lobe. Note sparse development of fissures and tubercles.

Dimensions: Maximum diameter about $1.25 \mathrm{~mm}$, height $0.65 \mathrm{~mm}$.

Provenance: From Middle Eocene (M. Lutetian), original type locality at Grignon, Paris Basin, France.

Depository: British Museum (Nat. Hist.). reg. No. P 52262 , Murray \& Wright Collection.

Hypotype (British Museum (Nat. Hist.) No. P 28647, Pl. 3 , fig. 2): Specimen rubbed down on ventral side to reveal periumbilical canal (last three chambers broken away). A large, well grown adult with 14 chambers in the last whorl. The umbilical partitions are clearly visible. The spiral, umbilical canal is closed by growth of pillars in the early part of the test but is still v.sible in the last part, despite damage to the final chambers.

Dimensions: Maximum diameter about $3.15 \mathrm{~mm}$

Provenance: From the Middle Eocene (Lutetian), Parnes, near Magny, NW of Paris.

Depository: British Museum (Nat. Hist.) reg. No. P 28647, T. R. Jones Collection. Figured previously by Davies (1932, pl. 2 , fig. 15) from which this photograph is reproduced. Specimen now virtually destroyed by subsequent attempt (by Davies?) to make thin-section. 
Hypotype (Vertical Section) (British Museum (Nat. Hist.) no. $P$ 28653, Text-fig. 3): A well grown adult with about $4 \frac{1}{2}$ whorls, showing the biconvex form of the test with the high domed dorsal side and thick, laminated wall with fine, elongate pores. The extension of the chamber lobes into the umbilical area can be seen as well as the thin, partial partitions formed by the toothplates. That connections exist between the umbilical 'space' and the surface fissures can also be clearly seen. Note also the massive development of the composite umbilical plug with irregular vertical canals between the pillars.

Dimensions: Maximum diameter about $3.15 \mathrm{~mm}$, height $1.65 \mathrm{~mm}$.

Provenance: From the Calcaire Grossier, Middle Eocene (Lutetian), Chaussy, Paris Basin.

Depository: British Museum (Nat. Hist.) reg. No. P 28653, ex T. R. Jones Collection. Figured by Davies (1932, pl. 3, fig. 12).

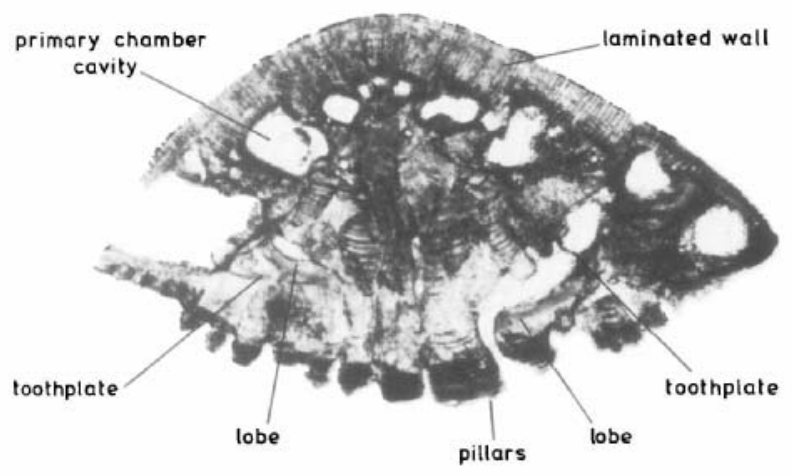

Fig. 3 Rotalia trochidiformis (Lamarck). Vertical section of adult hypotype, x23. T.R. Jones Collection, British Museum (Nat.Hist). No. P 28653. Figured by Davies (1932: pl. 3, fig. 12). From the Calcaire Grossier (Lutetian), at Chaussy, Paris Basin.

Remarks: The essential features of the species revealed by analysis of the paralectotype, topotypes and related material in the British Museum (Nat. Hist.) and the detailed redescription of a growth series are:

(a) Rotaliatrochidiformis sensu stricto can be relatively large (specimens reaching up to $4.5 \mathrm{~mm}$ have been recorded by Davies, 1932) with five to six whorls and up to 16 or 17 chambers in the last visible whorl. (b) Triangular umbilical (astral) lobes are a prominent feature of the juvenile stage becoming fused into a partial coverplate with growth. They are partially separated from the primary chamber cavity by a deep notch (astral furrow) and partial partition. The distal end of the final lobe is tucked into the umbilical side of the simple, basal aperture isolating the distal notch as a supplementary aperture.

(c) With growth the deep, ventral sutures (developed between the double septa) become secondarily excavated and prolonged by resorption across the astral lobes to form a system of open canals. The side walls of these fissures become incised with a dendritic system of secondary and tertiary fissures which in the adult are developed over the entire ventral surface apart from the peripheral margin and the last one or two chambers.

(d) There is progressive development of granulations along the edges of the septal canals leading to strong development of vertical pillars eventually covering the entire ventral surface, confined to a single whorl towards the periphery but fusing into a composite mass in the umbilicus.

(e) The umbilical space beneath the astral lobes remains relatively clear of pillars in the last few chambers and can be traced between the umbilical mass and the umbilical partitions as a spiral canal. The septal canals link with this space via the supplementary apertures and also with the vertical canals in the umbilical mass. The septal canals also link with the foraminal passage via sub-sutural canals ('interlocular spaces').

\section{THE ROTALIA TROCHIDIFORMIS GROUP}

Rotalia trochidiformis in the wide sense shows interesting variations both geographically and with time, though the precise relationships require further study. Typical forms, as described by Davies in his emendation of 1932 and redescribed here, may be confined to the Lutetian (Middle Eocene) of France. Even larger forms with six or seven whorls occur near Hauteville in the Cotentin with clearly marked spire on the dorsal side which is less embracing - described by Davies as $R$. trochidiformis var. hautevillensis. This subspecies occurs at the Lutetian/Auversian boundary but unfortunately it is not clear if $R$. trochidiformis hautevillensis represents a higher horizon than $R$. trochidiformis trochidiformis in the same local succession.

Specimens as large as those from the Paris Basin have not been discovered outside France. Although described as

\section{Explanation of Plate 1}

Figs 1-6 Rotalia trochidiformis (Lamarck). Fig. 1-1, Topotype. Stereo-pair of ventral view, x28. Showing fused umbilical lobes making star-shaped umbilical coverplate; the groove produced by resorption across penultimate lobe which prolongs the septal fissures or canal into the umbilical area. Murray \& Wright Collection, British Museum (Nat.Hist.) no P 49283. Figured by Murray \& Wright (1974: pl. 11, figs 4,5). From sample F134, Mid-Lutetian (M. Eocene), at Grignon, Paris Basin. Figs 2-2, 3, Topotype. Stereo-pair of ventral view and dorsal view, respectively, x28. Specimen donated by J.W. Murray, sample F132, at Grignon. British Museum (Nat. Hist.) no. P 52260. Figs 4-4, 5,6, Hypotype. Stereo-pair of ventral view, edge and dorsal views, respectively, x28. Well grown adult of about 4 whorls (compare to figs. $1-3$ for size relation to topotypes) with umbilical cover broken up by development of sutural canals and their tributaries. The edge view shows aperture and final umbilical lobe. L.M. Davies Collection, British Museum (Nat. Hist.) no. P 52261. From the Calcaire Grossier (Lutetian), at Chaussy, Paris Basin.

All SEM photographs, normal secondary electron images of coated material. 


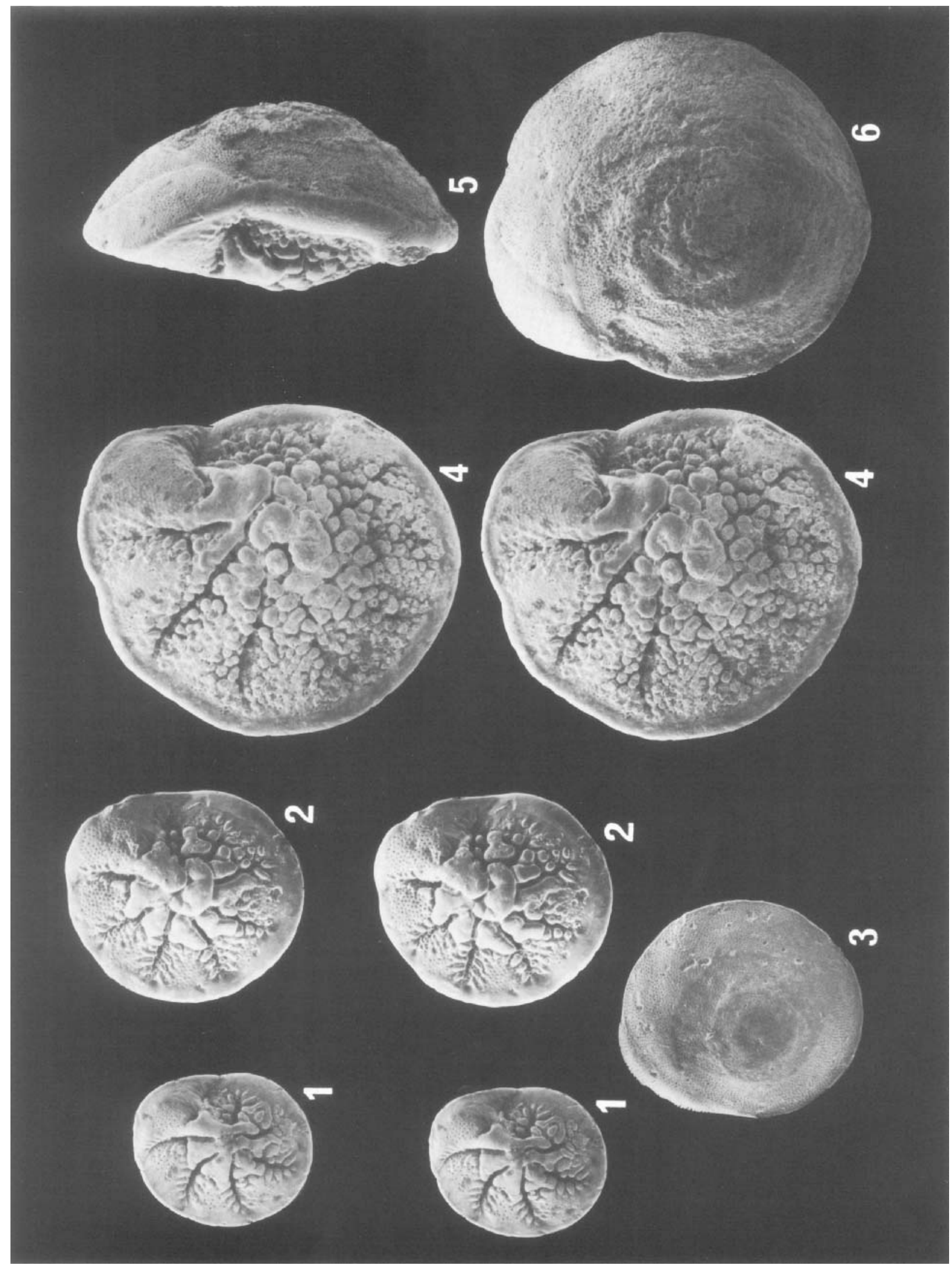


'typical' by Smout (1954), specimens from the Lower Eocene of Qatar reach a maximum of only $2.3 \mathrm{~mm}$ and average $1.6 \mathrm{~mm}$ maximum diameter with three whorls and 12-14 chambers in the final whorl. The specimens described by Gill (1953) similarly reach a maximum of $2.3 \mathrm{~mm}$. In neither case were apertural features discernible and thus they can only be assigned to $R$. trochidiformis trochidiformis with a question mark.

Specimens assigned to $R$. trochidiformis from the Palaeocene (Smout, 1954; Haynes, 1962) are smaller still, reaching only $1.0 \mathrm{~mm}$ in diameter with three to four whorls and 7-9 chambers visible at the periphery. These almost certainly represent a distinct species as they differ in apertural details. Rotalia cf trochidiformis of Pfender (1935) from the Palaeocene ('Montian') of Turkey similarly reaches only about $1.0 \mathrm{~mm}$ in maximum diameter but with up to 13 chambers in the last visible whorl. It is also high domed, without a keel and more coarsely perforate. It is illustrated in thin section only, as is Rotalia cf. trochidiformis of Gaetani et al. (1983) from the Palaeocene, Spanboth Formation of the NW Himalayas which reaches $1.6 \mathrm{~mm}$ diameter.

Rotalia trochidiformis has also been reported from the Upper Cretaceous but without useful figures or description. Many of the specimens appear to be small and may belong to other species. In the British Museum (Nat. Hist.) are specimens, identified at $R$. trochidiformis, from the Maestrichtian of Qatar (Henson Collection) which approach $2 \mathrm{~mm}$ in diameter; these require careful investigation beyond the scope of the present paper.

\section{DISCUSSION}

Our analysis shows that a major cause of confusion has been a misconception about the size of $R$. trochidiformis. Rotalia trochidiformis s.s. exceeds $4 \mathrm{~mm}$ in diameter in the adult and $R$. trochidiformis hautevillensis Davies, from the Contentin in western France, exceeds $5 \mathrm{~mm}$ diameter. This misconception arose in part because Davies (1932) deliberately chose a juvenile as lectotype (op. cit., pl. 3, figs 4,5,7), reaching only $1.9 \mathrm{~mm}$ maximum diameter, in order to illustrate astral lobes. Similarly Lévy et al. (1986) have illustrated juveniles of $R$. trochidiformis in order to show the discorbidlike nature of the lobes ('folia'). Strikingly, the specimen chosen by them to compare with Discorbis vesicularis lop.cit., pl. 1, fig. $1,1.4 \mathrm{~mm}$ maximum diameter) is actually smaller (pl. 1, fig. 4, $1.0 \mathrm{~mm}$ maximum diameter). Although we have also described topotypes that conform with Davies' lectotype care must be taken not to confuse the issue by comparing such juveniles with the adults of $D$. vesicularis.

The inclusion of material from outside the type area, possibly belonging to different subspecies, has also led to the idea that $R$. trochidiformis is relatively small. Haynes (1981: 285) himself fell into this trap and described Rotalia as 'small, up to 3 or 4 whorls' basing his ideas on specimens from the Palaeocene of Libya! Because of these mistakes, workers have not paid proper attention to the ontogenetic development of Rotalia trochidiformis s.s. and to those features only well expressed in the adult. This applies particularly to the open septal canal system and the dendritic fissures characteristic of the adult and which together with the massive development of pillars well distinguish Rotalia from Discorbis. A major problem for authors has been the difficulty of obtaining well grown species in recent years (see also above, p.96). Thus the maximum size of specimens (from Grignon) studied by Parvati (1971) was $1.9 \mathrm{~mm}$ and naturally she could not appreciate this development and described variation in the ventral aspect as...' 'generally associated with the development of secondary calcareous material, which may, or may not obliterate the coarse perforation of the primary wall, the spiral fissure, the astral fissures, the sutural fissures, etc. to the extent of presenting only a near chaotic pustulose and irregularly fissured surface'.

In Discorbis the septa appear to be doubled only where the toothplate is attached whereas in Rotalia this doubling continues across the septal face (see Müller-Merz, 1980) which allows the deep entrenchment of the sutures on the ventral side. In their assumption that the doubling of the septa is essentially the same in Rotalia and in Discorbis, Lévy et al. appear to have followed Davies (1932) who described the entrenched sutures on the ventral side in Rotalia as furrows 'produced by the puckering up of the chamber floor to form double septa between successive chambers' which suggests restriction to the umbilical area on the ventral side.

The first worker to observe that the septal sutures become entrenched on the ventral side was Cushman (1927). Although denied by a number of other researchers our material clearly shows how this occurs by resorption during growth with prolongation of the canals across the umbilical lobes. The further development of dendritic fissures into the side walls, feeding into the entrenched sutures produces an open canal system which may have facilitated protoplasmic inflow concomitant with outflow from the aperture. Through concentration upon the characters of the juvenile, Lévy et al.

\section{Explanation of Plate 2}

Figs 1-3 Rotalia trochidiformis (Lamarck). Fig. 1-1, Hypotype. Stereo-pair showing ventral view, x28. Broken final chamber revealing septal flap extending umbilically into toothplate. Note continuation of septal canal across penultimate umbilical lobe. T.R. Jones Collection, British Museum (Nat.Hist.) no. P 27275. Figured by Davies (1932: pl.4, fig. 3). From the Calcaire Grossier (Lutetian), at Chaussy, Paris Basin. Fig. 2-2, Hypotype. Stereo-pair showing ventral view of specimen with out 4\% whorls, x28. Last chamber broken revealing septal flap. T.R. Jones Collection, British Museum (Nat. Hist.) no. P 27276. Figured by Davies (1932: pl. 4, fig. 6). From Chaussy. Fig. 3, Hypotype. Ventral view of well grown adult with approximately 5 whorls and highly developed fissures and pillars, x28. L.M. Davies Collection, British Museum (Nat.Hist.) no. P 934. Figured by Davies (1932: pl. 3; fig. 13; pl. 4, fig. 9). From Parnes (Lutetian), Paris Basin

All SEM photographs, normal secondary electron images of coated material. 


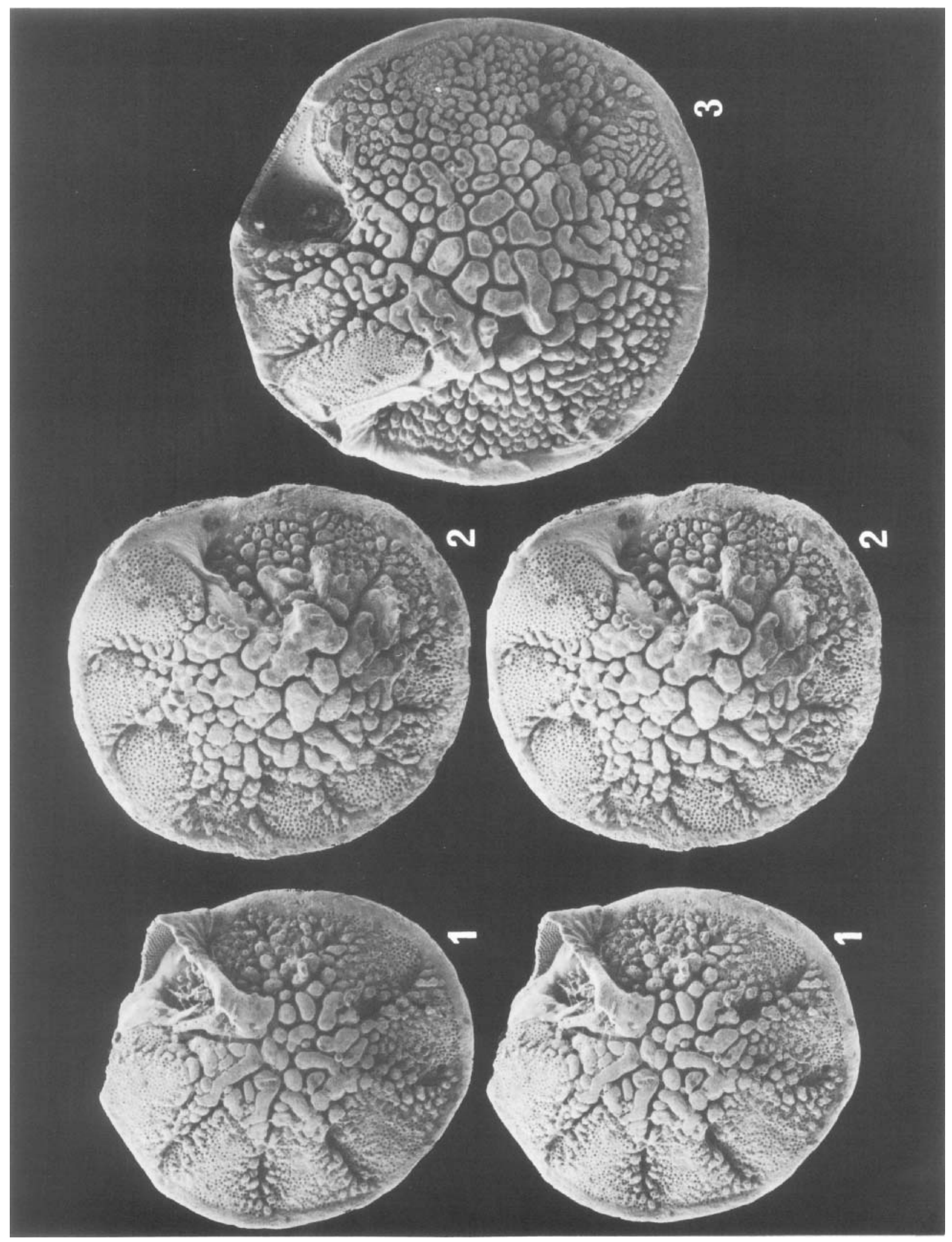


missed the significance of the fissures, dismissing them as merely, 'deep sutures' (op. cit., 1986: 65). They are also in some semantic confusion concerning canals. In their attempt to remove Rotalia from the Rotaliacea, as it were, they follow Reiss \& Merling (1958) who restrict the term 'canal system' to intra-lamellar structures and favour Smout's (1954) definition: 'Canal systems are complexes of essentially tubular cavities of relatively fine bore within the shell material. However, we believe this to be unnecessarily restrictive and our usage follows the original zoological definition of a canal as a duct or groove in the shell which falls within that of Loeblich \& Tappan (1988) who define it as an interlocular space, albeit 'usually tubular', and also that of Haynes (1981), who described canals as 'grooves or passages'.

The intralamellar spiral canals of the higher rotaliids begin as grooves on the primary lamella. There is, therefore, an ontogenetic and phylogenetic progression from open to closed canals. The terms would also seem to apply to the ring-like, peri-umbilical space finally produced between the composite plug and the toothplates. This was called an umbilical canal by Rijsinge (1930) and Smout (1954: 183), and a spiral canal by Parvati (1971), but dismissed by Davies (1932:409)...'What is more, there seems to be no function for a canal system lying along the umbilical line of open chamber mouths. Anything in the nature of a tube across this would not facilitate communication but block it...'. This shows he thought of a canal system as, necessarily, a kind of pipe-work. His figure of a cut specimen (op.cit., pl. 2, fig. 15), reproduced here as Pl. 3 , fig. 2, clearly shows the umbilical space.

Further, although Davies considered that the astral lobes resembled the star-like secondary chamberlets of Asterigerina, communication with the umbilical area and the exterior remains open ('labial apertures' of Reiss \& Merling, 1958) and closed umbilical chamberlets such as those in the Asterigerinacea are not formed.

One important feature of our results is the discovery of irregular vertical canals in the umbilical area (Fig. 3). These are less numerous and well developed than the 'funnels' described in Medocia by Parvati (1971). That genus also lacks secondary and tertiary fissures.

\section{CONCLUSIONS}

Rotalia trochidiformis s.s. approached $5 \mathrm{~mm}$ in diameter as a well-grown adult and is distinguished by triangular umbilical (astral) lobes which make a prominent cover-plate in the juvenile. With growth the progressive development of an open canal system and massive development of vertical pillars breaks up the cover-plate and the umbilical lobes are seen only in the last one or two chambers (if preserved). The similarity of the toothplates in Rotalia and Discorbis and the discorbid-like features of the juvenile in Rotalia trochidiformis are consistent with the idea of the origin of Rotalia from within the Discorbidae, possibly via intermediate, umbonate forms related to Rotorbinella of Bandy (1944). It need not lead us to doubt the integrity of the Rotaliidae which includes a number of large foraminiferal genera such as Lockhartia and Dictyoconoides with clear evolutionary links with Rotalia and distinctive distribution in space and (Palaeogene) time. We should remember that on general grounds derived from Neo-Darwinism and ecological population genetics that the separation between families at point of origin is no greater than that between related species/subspecies. However, our results show conclusively that Rotalia, as represented by the type, $R$. trochidiformis, is closer to Lockhartia and its allies than to the discorbids. Although we disagree with those authors who would incorporate Lockhartia and Dictyoconoides with Rotalia, the latest being Hofker (1971), their views underline our point about the relationships of these forms. It is important here not to be unduly influenced by the currently fashionable Neo-Linnean ('punctuationist') search for morphological gaps between species and by extension for bigger breaks between genera and between families, this approach inevitably leads to lumping of intergrading taxa.

A formal proposal by Lévy et al., (1986) that Rotalia be included in the Discorbidae and the superfamily name Rotaliacea be abandoned (op.cit.: 68)is therefore rejected.

\section{ACKNOWLEDGEMENTS}

Danielle Decrouez kindly facilitated the loan of the remaining Lamarck specimen from the Muséum d'Histoire naturelle, Geneva. Dr. F. T. Banner (British Museum (Nat.Hist.)) thoroughly read the manuscript, which by his constructive criticism, has been subsequently much improved. We are also indebted to Dennis Curry and Professor J.W. Murray (University of Southampton), who searched their personal collections for material from the type locality at Grignon.

\section{Manuscript received May 1989 \\ Revised manuscript accepted February 1990}

\section{Explanation of Plate 3}

Figs 1-5 Rotalia trochidiformis (Lamarck). Fig. 1-1, Topotype. Stereo-pair of specimen broken almost centrally to give natural vertical section revealing foramina and foraminal passage, x52. Murray and Wright Collection, British Museum (Nat.Hist.) no. P 52262. Fig. 2, Hypotype. Reproduction of Davies' (1932) pl.2, fig. 15, showing large adult specimen rubbed down on ventral side to reveal peri-umbilical canal, x20. British Museum (Nat. Hist.) no P 28647. Fig. 3-3, Topotype. Stereo-pair of opposite edge of specimen in fig. 1-1 broken to show interior of last two chambers and reveal umbilical partition, septal flap and double septum, x52. Fig. 4, Topotype. Oblique view of juvenile specimen shown in fig. 1-1 broken across to reveal internal details, x52. Fig. 5-5, Topotype, stereo-pair. Detailed peripheral view of interior of last chamber and astral lobe with lip and groove along its distal edge and secondary aperture, $x$ 155. Same specimen as in figs. 1, 3, 4 .

Figs. 1, 3-5 from Grignon (M. Lutetian), Paris Basin. Fig. 2 from Parnes (Lutetian), Paris Basin.

Abbreviations: a.f. - apertural face; a.l. - astral lobe; a.n. - astral notch (secondary aperture); d.s. - double septum; f - foramen; f.p. foraminal passage; 1.a. - 'labial aperture'; s.c. - septal canal; s.f. - secondary fissures; s.p. - septal flap; ss.c. - subsutural canal; u.p. - umbilical partition. 

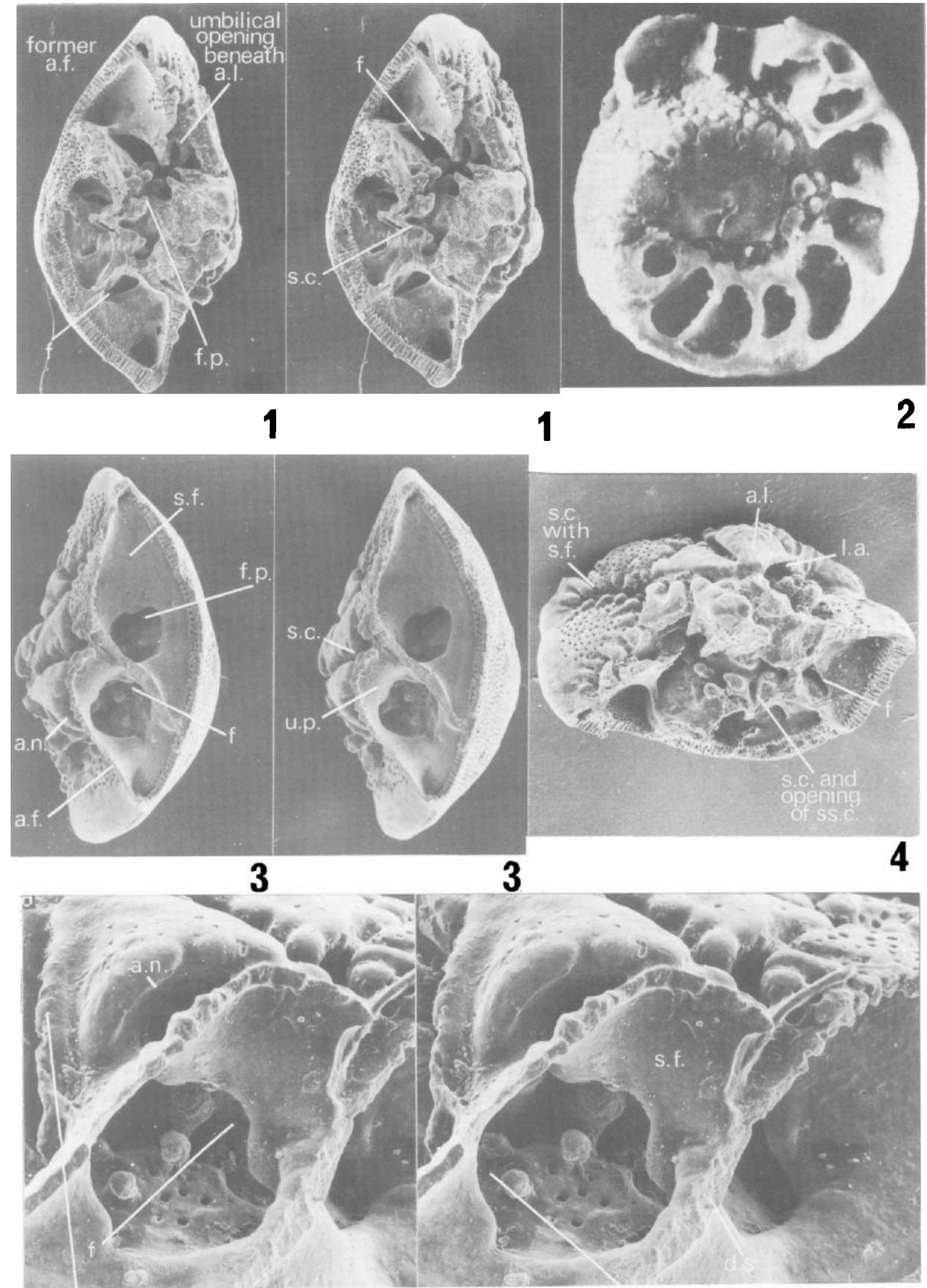

distal lip of a.I. and I.a.
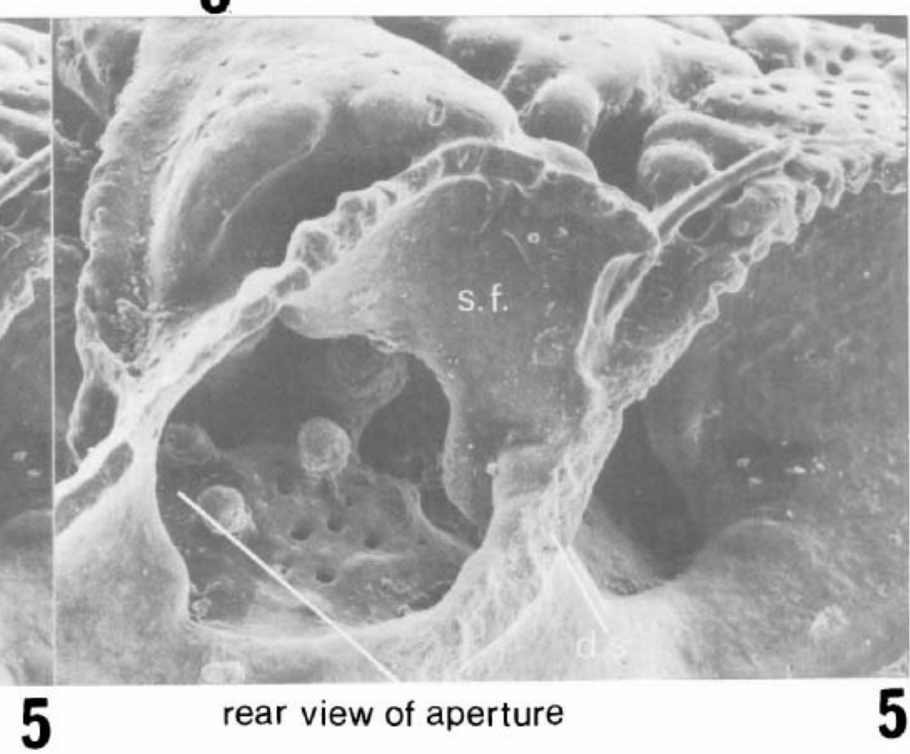


\section{REFERENCES}

Bandy, O.L. 1944. Eocene foraminifera from Cape Blanco, Oregon. J. Paleont., 18, 366-377

Barker. R.W.\& Grimsdale, T.F. 1937. Studies of Mexican fossil foraminifera. Ann. Mag.nat. Hist., ser 10, 19, 161-178

Brady, H.B. 1884. Report on the Foraminifera dredged by H.M.S. Challenger during the years 1873-76. Rep. scient. Results Voy. Challenger (zool.), 9, 1-814.

Bronn, H.G. 1824. System de Urweltlichen Konchylien... 56pp., J.C.B. Mohr, Heidelberg.

Brown, T. 1839. The Conchologist's Textbook. 5th Edition. 180pp., A. Fullarton, Glasgow, etc.

Brünnich, M.T. 1771. M.T. Brünnich Zoologiae fundamenta 253 pp. Grunde i Dyreloeren, Copenhagen \& Leipzig.

Carpenter, W.B., Parker, W.K.\& Jones. T.R. 1862.Introduction to the study of the Foraminifera. xxii $+319 \mathrm{pp}$., R. Hardwicke, London (for the Ray Society).

Cushman, J.A. 1927. Some notes on the early foraminiferal genera erected before 1808. Contr. Cushman Lab. foramin. Res., 3, 122-127.

Cushman, J.A. 1928. Foraminifera, their classification and economic use. Spec. Publs. Cushman Lab., 1, 1-401.

Davies, L.M. 1932. The genera Dictyoconoides Nuttall, Lockhartia nov. and Rotalia Lamarck: their type species, generic differences and fundamental distinction from the Dictyoconus group of forms. Trans. R.Soc. Edinb ., 57, 397428.

Ehrenberg, C.G. 1839. Über die Bildung der Kreidefelsen und des Kreidemergels durch unsichtbare Organismen. Phys.Math.Abh. K.Akad.Wiss.Berlin., 1838, 59-147.

Favre, J. 1918. Catalogue illustré de la Collection Lamarck. Mollusques Cephalopodes Fossiles. Muséum d'Histoire naturelle de Genève.

Gaetani, M., Nicora, A., Premoli Silva, I., Fois, E., Garzanti, E. \& Tintori, A. 1983. Upper Cretaceous and Paleocene in Zanskar Range (NW Himalaya). Riv. ital.Paleont.Stratigr., 89, $81-118$.

Gill, W.D. 1953. Facies and fauna in the Bhadras Beds of the Punjab Salt Range, Pakistan. J. Paleont., 27, 824-844.

Haque, M. 1962. The smaller foraminifera of the Meting Limestone (Lower Eocene), Meting, Hyderabad Division, W. Pakistan. Mem.geol. Surv.Pakist.Palaeont.pak., 2, 1139.

Haynes, J.R. 1962. Operculina and associated foraminifera from the Paleocene of the N.E. Fezzan, Libya. Contr. Cushman.Fdn.foramin.Res., 13, 90-97.

Haynes, J.R. 1981. Foraminifera. 433p., Macmillan, London etc.

Hofker, J.Sr. 1971. Studies of foraminifera. Part 3, Systematic problems. Publtiës natuurh. Genoot. Limburg, 21, 1-201.

Lamarck, J.B. 1801. Système des animaux sans vertèbres. Ist Edition. 432pp., The author, Paris.

Lamarck, J.B. 1804. Suite des mémoires sur les fossiles des environs de Paris. Annls Mus. Hist.nat. Paris, 5, 179-188.

Lamarck, J.B. 1806. Ibid., 8, 383-387.

Lankester, A.R. 1885. Protozoa. In The Encyclopaedia Britannica. 9th Edition. Vol. 19, 830-866. London.

Lévy, A., Mathieu, R., Poignant, A., Rosset-Moulinier, M. \& Rouvillois, A. 1982. Données nouvelles sur Rotalia trochidiformis Lamarck (Foraminiferida). Emendation du genre Rotalia Lamarck, 1804. Géolméditerr., 9, 33-41.

Lévy, A., Mathieu, R., Poignant, A. \& Rosset-Moulinier, M. 1984. Une nouvelle conception des familles Discorbidae et Rotaliidae. in Oertli, H.J. (Ed.), Benthos '83; Second
International Symposium on Benthic Foraminifera (Pau, April 1983), pp. 381-387. Pau \& Bordeaux.

Lévy, A., Mathieu, R., Poignant, A., \& Rosset-Moulinier, M. 1986. Discorbidae and Rotaliidae: a classification to be revised. J.foramin. Res., 16, 63-70.

Loeblich, A.R. Jr. \& Tappan, H. 1964. Protista 2. Sarcodina chiefly 'Thecamoebians' and Foraminiferida. In Moore, R.C. (Ed.) Treatise on Invertebrate Paleontology, Part C. 2 vols. 900pp., Geological Society of America \& University of Kansas Press, Lawrence.

Loeblich, A. R. Jr. \& Tappan, H. 1988. Foraminiferal genera and theirclassification vol.1.970pp., Van Nostrand Reinhold, New York.

Maync, W. 1952. Critical taxonomic study and nomenclatoral study of the Lituolidae based upon the prototype of the family, Lituola nautiloidea Lamarck, 1804. Contr.Cushman Fdn. Foramin.Res., 3, 35-56.

Müller-Merz, E. 1980. Strukturanalyse ausgewählter rotaloider Foraminiferen (Structural analysis of selected Rotaliid foraminifera). Schweiz.palaeont.Abh., 101, 5-70.

Murray, J. W. \& Wright, C.A. 1974. Palaeogene Foraminiferida and palaeoecology, Hampshire and Paris Basins and the English Channel. Spec.Pap.Palaeont., 14, 1-129.

Orbigny, A.C. d'. 1826. Tableau méthodique de la classe de Céphalopodes. Annls Sci.nat.,Paris, ser. 1, 7, 96-314.

Parvati, S. 1971. A study of some rotaliid foraminifera, $1 \& 2$. Proc,K.ned.Akad.Wet., ser. B, 74, 1-26.

Pfender, J. 1935. A propos du Siderolites vidale Douvillé et de quelques autres. Bull.Soc.géol.Fr., ser. 5, 4, 225-236.

Reiss, Z. \& Merling, P. 1958. Structure of some Rotaliidea. Bull. geol.Surv. Israel, 21, 1-19.

Reuss, A. E. 1846. 5. Ordn. Polythalamia. Schnörkelkorallen. In Geinitz, H.B., Grundriss der Versteinerungskunde, pp. 635696. Dresden \& Leipzig.

Rijsinge, C. van. 1930. Some remarks on Dictyoconoides Nuttall ( $=$ Conulites Carter $=$ Rotalia Lamarck). Ann.Mag.nat.Hist., ser. 10, 5, 116-135.

Smout, A. H. 1954. Lower Tertiary foraminifera of the Qatar Peninsular. 96pp., British Museum (Natural History), London.

Taylor, P. D. 1986. Scanning electron microscopy of uncoated fossils. Palaeontology, 29, 685-690. 